\title{
The Manifesto on European Criminal Policy in 2011
}

\author{
By the European Criminal Policy Initiative
}

In December 2009 the "European Criminal Policy Initiative", an international research group consisting of 14 university professors from ten Member States of the European Union published the so called "Manifesto on European Criminal Policy" in the German Online-Journal "Zeitschrift für Internationale Strafrechtsdogmatik" (www.zis-online.com) in seven languages. The principles and guidelines for a reasonable criminal policy on the European level established therein have attracted great interest throughout the European Union (and also beyond the Union's borders $^{1}$ ). The Manifesto has been discussed at international seminars and conferences, commented in numerous articles throughout Europe and even taken into consideration by the European institutions ${ }^{2}$.

The Manifesto consists of two parts: The first part exposes the general principles, which are completely rooted in and therefore in conformity with European law. The second part may be even more important for practical use as it contains a critical approach to existing legal acts or concrete proposals for future acts. The purpose of this part of the Manifesto is to check whether the legal acts mentioned here are in line with the demands of the Manifesto or whether amendments are advisable.

The text of the Manifesto printed below has (slightly) been adapted: the second part of the Manifesto - being a kind of "living instrument" - will be continuously adjusted and supplemented by the members of the ECPI according to the legislative progress in the European Union. As to the first part only few editorial amendments have been made, taking into account the entry into force of the Treaty of Lisbon on 1st December 2009 (which was still uncertain at the time when the original version of the Manifesto was finally edited).

\section{Manifesto on European Criminal Policy ${ }^{3}$ \\ Preamble}

The undersigned criminal law scholars from ten European countries would like to present their proposal for European criminal policy.

This Manifesto is based on the principles rooted in the common European Enlightenment tradition, namely

- in recognition of the fact that the spirit of Enlightenment is the major contributor to and the motor of European civilisation and current integration, and that it should guide us in the preservation of European culture and future cooperation between European countries; and

\footnotetext{
${ }^{1}$ See e. g. the translation into the Georgian language, Turava, European Criminal Law,Tbilisi 2010, p. 523-539

${ }^{2}$ See preface of the Vicepresident of the European Commission Reding, EuCLR 2011, p.5 (this edition)

${ }^{3}$ By the European Criminal Policy Initiative; for further information see www.crimpol.eu.
} 
- being convinced that criminal law legislation must adhere to the highest standard of democratic legitimacy and the rule of law (Rechtsstaatlichkeit) and that the future of European security can only be safeguarded within a system based on the concepts of democracy, freedom and fundamental legal principles.

This Manifesto reflects the dynamics of European integration, calling attention to the fact that substantive criminal law and criminal procedure law are increasingly becoming the focus of European legislation. At present, European legal instruments used for the harmonisation of criminal legislation already exert influence on the existing national legal frameworks of substantive criminal law and criminal procedure law. Due to the amendments brought about by the Lisbon Treaty this tendency will be even stronger in future. The European institutions making criminal policy decisions on a large scale have failed to acknowledge criminal policy as an autonomous European policy. As a consequence they do not follow a coherent concept of criminal policy.

The Manifesto Group is convinced that Europe needs a balanced and coherent concept of criminal policy based on a number of fundamental principles (as listed below). These principles should be recognised as a basis for every single legal instrument which deals with or which could influence criminal law. The European legislator has to justify the relevance of its proposals in relation to the principles and standards of good governance. The criminal law principles constitute an integral part of the shared European criminal law tradition and can be derived from the normative structure of the European Union (EU).

\section{The fundamental principles of criminal policy}

\section{The requirement of a legitimate purpose}

The legislative powers of the EU in relation to criminal law issues should only be exercised in order to protect fundamental interests if:

(1) These interests can be derived from the primary legislation of the EU;

(2) The Constitutions of the Member States and the fundamental principles of the

EU Charter of Fundamentals Rights are not violated, and

(3) The activities in question could cause significant damage to society or individuals.

The requirement of a legitimate purpose can be derived from the European principle of proportionality. European legislation can be regarded as legitimate and proportionate only if criminal law is used in order to safeguard the fundamental interests of its citizens.

In accordance with the requirement of good governance the EU legislator has to provide a detailed justification for its legislation, including a thorough explanation of why the interests in question shall be regarded as being of fundamental importance, and why the act marked as a criminal offence shall be considered to have a considerable negative impact on the interests concerned. Enforcement of the 
objectives and policies of the European Union cannot, by itself, legitimise the criminalisation of an act.

\section{The ultima ratio principle}

Since the European Union places the individual centre stage, the European legislator may only demand that an act be criminalised if it is necessary in order to protect a fundamental interest, and if all other measures have proved insufficient to safeguard that interest.

Only if this condition has been satisfied can criminal law be regarded as 'necessary' and in conformance with the European principle of proportionality. This is also due to the fact that criminal sanctions entail social stigmatisation which significantly affects citizens' rights, including the rights expressed in the EU Charter of Fundamental Rights. Furthermore, excessive use of criminal sanctions and criminalisation leads to a decline in the efficiency of criminal law.

Bearing in mind the principles of good governance, it is the responsibility of the European legislative bodies to justify their use of criminal sanctions as the last resort of social control.

\section{The principle of guilt (mens rea)}

European legislation requiring the Member States to criminalise certain acts must be based, without exception, on the principle of individual guilt (the principle of nulla poena sine culpa).

This requirement captures not only the fact that criminalisation should be used solely against conduct which is seriously prejudicial to society, but that it should also be regarded as a guarantee that human dignity will be respected by criminal law. Furthermore, the requirement of individual guilt is in conformity with the generally accepted perception of guilt within the system of administrative sanctions in the EU and can also be inferred from the presumption of innocence in Art. 48 (1) of the EU Charter of Fundamental Rights.

As a consequence the European legislator has to justify that the requirements in European legislation as to the sanctions permits the imposition of penalties which correspond to the guilt of the individual and which are not disproportionate to the criminal offence.

This does not predetermine the answer to the question of whether legal entities can be held criminally liable. There is a decisive difference between guilt of an individual and that of a legal entity. Rules concerning criminal liability of legal entities must thus be elaborated on the basis of criminal law provisions at the national level.

\section{The principle of legality}

In order to respect the fundamental rule of law requirements a criminal law system must adhere to the principle of legality. This principle, including its different 
sub-principles, is regarded as a general principle of law, as codified in Art. 6 (3) of the Treaty on European Union or in Art. 7 (1) of the European Convention on Human Rights as well as in Art. 49 (1) of the EU Charter of Fundamental Rights. For the purposes of criminal policy three central requirements which should be respected by the European legislator can be derived from this principle.

\section{a) Subprinciple 1: The lex certa requirement}

In European legal reasoning the principle of legal certainty requires that an individual shall be able to predict actions that will make him criminally liable. This means that criminal law provisions must define offences in a strict and unambiguous way. This implies above all utmost clarity: the normative proscriptions should be understandable 'on their own'. Under any circumstances the norm must ensure that (1) the objective and (2) the subjective prerequisites for criminal liability as well as (3) sanctions which could be imposed if an offence is committed are foreseeable.

Although the subsidiary character of harmonisation work at EU-level necessarily requires that the Member states have a certain degree of latitude in drafting the details of implementation (which implies a certain degree of vagueness as regards European legislative acts), the lex certa requirement is nevertheless important for EU legal instruments as a general principle of law and a fundamental element of any criminal law system based on the rule of law.

The smaller the margin of freedom at the level of implementation, the more important it is that the European legislative acts satisfy the lex certa requirement. If a certain European legal instrument seeks to fully harmonise the proscriptions in the Member States, it should satisfy the lex certa requirement in the same way as if it were a criminal law provision.

When a rule which obliges the Member States to take criminal law measures refers to other European provisions, the abovementioned requirements must be applied to the relevant European legislation taken as a whole. Otherwise it will be almost impossible to create national provisions that meet the lex certa requirement.

\section{b) Subprinciple 2: The requirements of non-retroactivity and the prin- ciple of lex mitior}

Punitive provisions must not apply retroactively to the detriment of the citizen involved. This principle, which also helps to reinforce foreseeability, implies that the European legislator cannot request that the Member States harmonise their criminal law by introducing criminal legislation to apply retroactively.

An exception to this basic rule is permissible only when retroactive criminal law benefits the offender. Criminal law provisions which come into effect after the commission of the offence, but which are favourable to the offender (i.e. according to which the act is not punishable or carries a lighter penalty than before), can be applied as a basis for conviction without violating the requirement of non-retroactivity (the lexmitior principle). The lex mitior principle is recognized by all Member 
States, but there are differences as regards its normative status, especially as regards the question of whether the principle is of constitutional character. In the case law of the European Court of Justice (Case Berlusconi) as well as according to Article 49 (1) of the EU Charter of Fundamental Rights, the principle is considered, however, to be of utmost importance. The European legislator is therefore bound by this principle and cannot, by means of instruments of harmonisation, oblige the Member States to apply the law that was applicable when the offence was committed if this law has been altered afterwards in a way which is favourable for the defendant.

\section{c) Subprinciple 3: Nulla poena sine lege parlamentaria (no penalty without a law)}

Since criminal law is the most intrusive of the institutions of state control, in a democratic society it must be justified by reference to as direct participation as possible by the people in the legislative process. To the extent that the EU does not have, or does not make use of a competence to make supranational criminal legislation, the competence to adopt criminal law provisions remains the preserve of the Member States (i.e. their national Parliaments). Due to the fact that the European legislator can issue binding instruments which national Parliaments must comply with, constraints that impact on the freedom of national legislatures are placed on them. This means that even instruments of harmonisation must be justifiable from the point of view of democracy. As far as European instruments limit the freedom of the national legislator, the harmonised criminal law provision cannot be justified on the grounds of democracy at the national level. This makes it necessary to strengthen democratic legitimacy at the European level by a more active role of the European Parliament in the Union's legislative process.

The wider application of the co-decision procedure provided for in the Lisbon Treaty is therefore - at least from the point of view of democratic legitimacy - most desirable.

In order to achieve a satisfactory level of democratic legitimacy in regard of secondary legislation with criminal law implications, and to ensure wide acceptance of such measures, the institutions involved in the legislative process must - also now after the changes provided for by the Lisbon Treaty have come into effect - make sure that the national parliaments are informed in any case as early and as thoroughly as possible. This will enable the Member States to actually influence the final form and content of the instruments (and the voting of their representatives in the Council). Before legislative decisions are made an equal co-operation between the Member states and the European institutions and among Member states is necessary for installing a sufficient level of democratic control. This is essential in order to respect the 'good governance' principle since it ensures that the results are transparent and reasonable as regards legal policy. It will also facilitate broader civil society participation in the legislative process. 


\section{The principle of subsidiarity}

Instruments which are relevant for criminal law and which are enacted on the basis of shared competences in accordance with the general rules of EU law must meet the requirement of subsidiarity. According to this principle the EU legislator may take action only on the condition that the goal pursued

(1) cannot be reached more effectively by measures taken at national level and

(2) due to its nature or scope can be better achieved at Community level.

Accordingly, the national legislator will be given priority in relation to the European legislator to the extent that the Member state is capable of dealing with a given issue. In this way the citizens will be brought closer to decision making in criminal legislation.

The principle of subsidiarity is of special importance in the area of criminal law, since criminal law is also a value system, and as such it is a component part of the 'national identities' of the Member states, which must be respected by the Union in accordance with Art. 4 (2) of the Treaty on European Union.

The test of subsidiarity should be applied separately in every single case, i. e. in relation to every instrument and each part of that instrument. Legislative measures must be thoroughly justified in accordance with the protocol on subsidiarity (Protocol no. 2 of the Lisbon Treaty); the national parliaments must be involved as provided for therein.

\section{The principle of coherence}

The invasive character of criminal law makes it especially important to ensure that every criminal law system is a coherent system. Such inherent coherence is a necessary condition if criminal law is to be able to reflect the values held to be important by society collectively and by individuals and their understanding of justice. Inner coherence is, furthermore, necessary in order to ensure acceptance of criminal law.

When enacting instruments which affect criminal law, the European legislator should pay special attention to the coherence of the national criminal law systems, which constitute part of the identities of the Member states, and which are protected under Article 4 (2) of the Treaty on European Union (vertical coherence). This means, first and foremost, that the minimum-maximum penalties provided for in different EU instruments must not create a need for increasing the maximum penalties in a way which would conflict with the existing systems. In addition, the European legislator must pay regard to the framework provided for in different EUinstruments (horizontal coherence, cf. Art. 11 (3) Treaty on European Union).

To be in line with the principle of good governance before enacting any illegal instrument the European legislator should evaluate the consequences for the coherence parameters of the national criminal law systems, as well as for the European legal system, and on this basis explicitly justify the conclusion that the legal instruments is satisfactory from this point of view. 


\section{Annotations to the fundamental principles of criminal policy}

The above mentioned principles can and should be guidelines for a reasonable legislation as regards criminal policy aspects. As such they can be used to examine already enacted and proposed legal acts in respect of their justification on a criminal policy level. The examination points out the practical relevance and urgency of our requirements. The following part of the Manifesto emphasizes on the one hand already existing commendable approaches for a good criminal policy which can be exemplary for further legislation in the field of criminal law. On the other hand, however, it points out the weak spots that need a correction pursuant to our guidelines.

1. Undoubtedly there are several legal acts that meet the requirement of a legitimate purpose:

- For example the legislative acts on combating trafficking in human beings ${ }^{4}$ seek to protect fundamental legitimate interests. The use of deceit, coercion or even force for the purpose of sexual or labour exploitation of vulnerable persons is not acceptable within an area of freedom, security and justice. Such conduct violates the victim's core individual rights (physical integrity, freedom of will, sexual self-determination, labour), also protected by the Charter of Fundamental Rights of the European Union.

- Furthermore the Convention on the protection of the European Communities' financial interests ${ }^{5}$ and its protocols pursue a legitimate purpose, namely the preservation of the financial independence and capacity of the European Union.

However, there are legal acts that do not seem to respect the requirement of a legitimate purpose:

- The Framework Decision on combating the sexual exploitation of children and child pornography ${ }^{6}$ undoubtedly pursues a legitimate concern of criminal policy, namely the protection of the minors involved. However, in its Art. 1 (b) (ii) and (iii) the framework decision goes far beyond that aim by involving the depiction of adults appearing to be a child and realistic images of a non-existent child, for example by computer animation (virtual child pornography). Such depictions do not directly harm a minor, as the represented person is either an adult or not even an existent person. No evidence has been provided yet that such depictions cause indirect danger for minors. To act in accordance with our demands the European legislator should furthermore make an effort to justify the need for the provision (if necessary on the basis of empirical investiga-

\footnotetext{
${ }^{4}$ Council Framework Decision 2002/629/JHA, OJ 2002 L 203, p. 1; Proposal for a Directive on preventing and combating trafficking in human beings, and protecting victims, repealing Framework Decision 2002/629/JHA, COM (2010) 95 final.

${ }^{5}$ OJ 1995 C 316, p. 49; OJ 1996 C 313, p. 2; OJ C 221, p.12.

${ }^{6}$ Council Framework Decision 2004/68/JHA, OJ 2004 L 13, p. 44; cf. now the Proposal for a Directive on combating the sexual abuse, sexual exploitation of children and child pornography, repealing Framework Decision 2004/68/JHA, Council Doc. 16958/10.
} 
tions). Only then the extent of criminalisation can be justified by a "legitimate purpose".

- According to the Framework Decision on the fight against organised crime $^{7}$ the Member States are to criminalise either participation in the criminal activities of a criminal organisation, Art. 2 (a), or the agreement of particular offences, Art. 2 (b), (comparable to the Anglo-Saxon model of "conspiracy"). However, the interests that may be harmed and thus the legitimate purpose remain vague. The provision prescribes a minimum-maximum penalty of four years but it is not apparent which kind of illegal activities or particular offences are included by the provision. The provision only requires the members of the criminal organisation to act with the intention to obtain, directly or indirectly, a financial or other material benefit. This describes the motivation of the perpetrator, not the legitimate purpose which the conduct is aiming at. Hence the provision does not sufficiently reveal its aim (except for the diffuse fight against organised crime). The Member States do not receive a clear impression of what they have to criminalise. In any case, if no further explanations are presented the European legislator violates the principle of good governance.

2. The principle of ultima ratio which can be derived from the (European) principle of proportionality has been respected in the following legal acts:

- The Directive on providing for minimum standards on sanctions and measures against employers of illegally staying third-country nationals ${ }^{8}$ demonstrates a positive trend: According to Art. 9 of this directive only particular cases which go beyond the mere infringement of the prohibition of illegal employment, Art. 3 (1), constitute a criminal offence. The Member States only have to punish illegal employment if committed in aggravating circumstances such as: the continuous and persistent infringement, the simultaneous employment of a significant number of illegal staying third-country nationals, the illegal employment of a minor, particularly exploitative working conditions or employment with the knowledge that the illegally staying third-country national is a victim of trafficking in human beings. For the mere infringement of the prohibition of illegal employment, established in Art. 3 (1), sanctions of a non-criminal character (for example administrative sanctions) are sufficient. The legislator has (intentionally?) taken into account the principle of proportionality and hence the principle of ultima ratio.

- The Framework Decision on attacks against information systems ${ }^{9}$ requires the Member States to punish the illegal access to information systems (Art. 2) the hindering or interruption of the functioning of an information system (Art. 3) and different kinds of data interference (Art. 4). To limit the extension of criminal liability the legal act excludes so called minor cases. Furthermore the Member States may decide whether they want to criminalise the attempt to

\footnotetext{
${ }^{7}$ Council Framework Decision 2008/841/JHA, OJ 2008 L 300, p. 42.

${ }^{8}$ Directive 2009/52/EC, OJ 2009 L 168, p. 24.

${ }^{9}$ Council Framework Decision 2005/222/JHA, OJ 2005 L 69, p. 67.
} 
commit the offence established in Art. 2. ${ }^{10}$ It is questionable, whether such provisions are sufficient to limit the extension of criminal liability. Still the European legislator is steering in the right direction. Such provisions make it possible for the Member States to reconcile the required legislative measures with their existing provisions concerning their scope. They are furthermore in accordance with the principle of coherence.

- According to Art. 2 (2) of the Framework Decision on illicit drug trafficking $^{11}$ the Member States are not obligated to punish acts which are (exclusively) related to the perpetrators own consumption. Given the different approaches of drug policy and different significance of narcotics offences in the Member States, it should be acknowledged that by this exclusion the European legislator gives the Member States a certain leeway in respect of their criminal policy.

However, there are still examples showing that the European legislator does not continuously pay attention to the principle of ultima-ratio and that he ignored the justification required by the principle of good governance.

- The amending Framework Decision on combating terrorism ${ }^{12}$ requires the Member States to classify the following conduct as offences linked to terrorist activities: the public provocation to commit a terrorist offence, the recruitment and training for terrorism, as well as the aiding or abetting, inciting and attempting. The provision is also supposed to counteract the tendency of using the internet as a "virtual training camp" for terrorists. However, the provision criminalises conduct that is committed before the actual commission of a terrorist offence. The European legislator leads the Member States to a criminal law that tries to prevent even mere dangers for legally protected interests. The provision criminalises conduct only leading to a criminal attitude of other persons or only supporting such attitude (super-pre-preventative criminal law). Such extended criminal liability (Vorverlagerung der Strafbarkeit) abandons the requirement of even an abstract danger for a legally protected interest and hence is not compatible with the European principle of proportionality (and derived from that the principle of ultima ratio) which is an essential guideline for criminal policy. ${ }^{13}$ As long as a certain conduct does not even constitute a present danger for legally protected interests, its criminalisation is not necessary. In any case the European legislator should give - in accordance with the principle of good governance - a detailed justification why he did not impose a less severe measure, such as increasing monitoring of the internet or obligating operators of websites.

- A similar critical extension of criminal liability is evident in the Framework Decision on combating fraud and counterfeiting of non-cash means of

\footnotetext{
${ }^{10}$ Regrettably different in that point the Propopsal for a Directive on attacks against information systems and repealing Council Framework Decision2005/222/JHA, COM (2010) 517 final.

${ }^{11}$ Council Framework Decision 2004/757/JHA, OJ 2004 L 335, p. 8.

12 Council Framework Decision 2008/919/JHA, OJ 2008 L 330, p. 21.

${ }^{13}$ Similar tendencies of such extended criminal liability can be found in many other framework decisions, for example in Art. 2 (c) of the Framework Decision on combating fraud and counterfeiting of non-cash means of payment, 2001/413/JHA, OJ 2001 L 149, p. 1.
} 
payment. ${ }^{14}$ The provision is supposed to cover the whole range of activities that together constitute the menace of organised crime in this regard (recital no. 8). The Members States are obligated to criminalise even the making or obtaining of objects that only hypothetically could be used for the commission of an offence. Given the marginal risk potential at this early stage it takes more than the mere reference to organised criminality to comply with the requirement of good governance.

- The Framework Decision on the fight against organised crime ${ }^{15}$ is not limited to criminal organisations with a certain degree of organisation. According to Art. 1 no. 2 the instrument includes every association that is not randomly formed nor does it need to have formally defined roles for its members, continuity of its membership, or a developed structure. Hence the obligation to criminalise goes further than required by the antisocial nature of organised crime which can hardly be justified considering the principle of proportionality.

- The Directive on the protection of the environment through criminal law $^{16}$ shows similar problems. The legal act requires the Member States to criminalise conduct that infringes other prohibitions community law. This obliges to criminalise wrongdoing of merely formal character. According to Art. 3 (c) of the directive it already constitutes an illegal shipment of waste if the shipment effects without notification to all competent authorities concerned (compare Art. 2 no. 35 (a) of the Regulation (EC) 1013/2006) or in a way which is not specified materially in the notification or movement documents (compare Art. 2 no. 35 (d) and (g) (iii) of the Regulation (EC) 1013/2006). The criminalisation of administrative offences does not comply with the European principle of proportionality and its sub-principle, the principle of ultima ratio. Furthermore, in such cases no interests that require protection by means of criminal law are at risk.

- The Framework Decision on combating corruption in the private sector $^{17}$ is not supported by any arguments why less severe means to prevent corruption in this field do not suffice, such as civil claims for compensation or comprehensive compliance measures (for example the establishment of the foureyes principle for the award of contracts or the regular replacement of employees in contracting departments). The European legislator has not sufficiently considered his duty to give reasons for the use of criminal law as a last resort for social control.

3. There are some examples of legal acts in the field of criminal law that respect the principle of guilt:

- In some Member States rules on criminal liability for legal persons would not be compatible with their concept of the principle of guilt, forming the basis of their

\footnotetext{
${ }^{14}$ Council Framework Decision 2001/413/JHA, OJ 2001 L 149, p. 1.

${ }^{15}$ Council Framework Decision 2008/841/JHA, OJ 2008 L 300, p. 42.

${ }^{16}$ Directive 2008/99/EC, OJ 2008 L 328, p. 28.

${ }^{17}$ Council Framework Decision 2003/568/JHA, OJ 2003 L 192, p. 54.
} 
national criminal law system. There are framework decisions that obligate the Member States to impose sanctions on legal person. However, it should be positively noted that as yet it is up to the Member States whether they fulfil this obligation by means of criminal law. An example is Art. 6 of the Framework Decision on combating corruption in the private sector. ${ }^{18}$ Such reserve should be maintained.

- Furthermore it should be acknowledged that some legal acts require the offence to be committed intentionally, for example the Framework Decision on combating fraud and counterfeiting of non-cash means of payment ${ }^{19}$, Art. 4 (1), and the Convention on the protection of the European Communities' financial interests. ${ }^{20}$ However this important requirement rests on shaky foundations and can easily be circumvent, due to the fact that Art. 1 (4) of the Convention allows to infer the intentional character from objective circumstances.

Regarding the principle of guilt it is furthermore alarming that the legislator does not pay attention to the fact that the penalty scale should be in due proportion to the dangerousness of the offence.

- The Framework Decision on combating terrorism ${ }^{21}$ requires the Member States to criminalise the directing of a terrorist group, Art. 2 (2) (a), and the knowing participation in the activities of a terrorist group, for example by supplying information or material resources or by funding its activities, Art. 2 (2) (b). In its Art. 5 (3) the provision establishes a maximum sentence of not less than fifteen years for the offences listed in Art. 2 (2) (a) and for the offences listed in Art. 2 (2) (b) a maximum sentence of not less than eight years. Regarding the principle of guilt respectively the proportionality of penalty scales it may be problematic that terrorist groups are not necessarily targeted on the commission of grave offences (such as attacks at a person's life or physical integrity, hostage taking or the production of weapons of mass destruction). In fact they may only be directed towards the threatening to commit terrorist offences, Art. 1 (1) (i).

As regards the "participation in the activities of a terrorist group" the framework decision establishes a maximum sentence of not less than eight years, regardless of whether the group target the commission or only the threatening to commit terrorist offences. No expression is given to the fact that the different kinds of participation vary in their dangerousness. The legislator did not sufficiently regard the severity of guilt.

As to the "directing of a terrorist group" it is even more questionable whether the principle of guilt has been respected. On the one hand Art. 5 (3) reduces the minimum-maximum penalty for the directing of a terrorist group that refers only to the threatening to commit terrorist offences (eight years instead of fifteen).

\footnotetext{
${ }^{18}$ Council Framework Decision 2003/568/JHA, OJ 2003 L 192, p. 54.

${ }^{19}$ Council Framework Decision 2001/413/JHA, OJ 2001 L 149, p. 1.

${ }^{20}$ OJ 1995 C 316, p. 49.

${ }^{21}$ Council Framework Decision 2002/475/JHA, OJ 2002 L 164, p. 3 (amended by Council Framework Decision 2008/919/JHA, OJ 2008 L 330, p. 21).
} 
Given that the mere threatening to commit is less dangerous than the commission of a terrorist offence, the reduction of the sentence is commendable. On the other hand, the legislator establishes the same minimum-maximum sentence for both the leader of the group and the follower who participates in a terrorist group directed towards the mere threatening. Unfortunately the legislator failed to reduce the sentence for these participants.

By establishing the same minimum-maximum penalty for offences causing different social damages the European legislator violates the principle of guilt, respectively the requirement of proportional penalties.

- In its Art. 3 (1) the $\mathbf{2 0 0 9}$ Proposal for a Framework Decision on preventing and combating trafficking in human beings ${ }^{22}$ established a minimummaximum penalty of six years. This sentence should apply to "offences referred to in Art. 1 and 2". Art. 1 comprised the obligation to criminalise certain acts, Art. 2 required the Member States to punish the instigation, aiding, abetting or attempt. Hence the Commission envisaged the same minimum-maximum penalty for the commission of the offence on the one hand and for the participation or the attempt on the other hand. This is hardly consistent with the principle of guilt which requires a sentencing according to the participant's personal responsibility. With good reason aiding and abetting is punished less severely (at least optional) in many national criminal law systems. ${ }^{23}$

4. Regarding the wording of the legal acts in the field of criminal law, positive approaches must be noted in respect of the lex certa-principle (a sub-principle of the principle of legality):

- It is positive if the European legislator seeks a clear definition of the conduct that has to be criminalised by the Member States. A good example is Art. 3 (1) (c) of the Framework Decision on protection against counterfeiting in connection with the introduction of the euro. ${ }^{24}$ This instrument requires the Member States to criminalise the import, export, transport, receiving or obtaining of counterfeit currency. In addition the notion of "currency" is separately defined in Art. 1 of the framework decision. In a similar way Art. 2 (1) (a) of the Framework Decision on illicit drug trafficking ${ }^{25}$ instructs the Member States to criminalise the production, manufacture, extraction, preparation, offering, offering for sale, distribution, sale, delivery on any terms whatsoever, brokerage, dispatch, dispatch in transit, transport, importation or exportation of drugs. It must be acknowledged that the European legislator tries to define the material elements of the offence by numerous and to some extent concrete terms. However, the other side of the coin shows that the ambition to embrace every possible conduct in the catalogue of offences can lead to overlapping terms. A clear distinction between the modalities of the offence (for example the

\footnotetext{
${ }^{22}$ COM (2009) 136 final, p. 14.

${ }^{23}$ In this respect the Proposal for a Directive on preventing and combating trafficking in human beings, and protecting victims, repealing Framework Decision 2002/629/JHA, COM (2010) 95 final cannot be criticised.

${ }^{24}$ Council Framework Decision 2000/383/JHA, OJ 2000 L 140, p. 1.

${ }^{25}$ Council Framework Decision 2004/757/JHA, OJ 2004 L 335, p. 8.
} 
distinction between offering and offering for sale respectively delivery, dispatch and transport) is not possible. Furthermore it is questionable whether or not such an extensive obligation to punish complies with a reasonable criminal policy (whereas this is not an aspect of the lex certa-requirement, but of the principle of ultima-ratio).

- It deserves being mentioned that European institutions have sought to achieve a higher level of definiteness and clarity when transposing international law provisions set by other international organisations into EU law. For example Art. 1 (1) (c) of the Framework Decision on combating trafficking in human beings $^{26}$ clarifies the wording of the corresponding United Nations protocol. An act shall be punishable under the UN protocol and the framework decision where there is an ,abuse of authority or of a position of vulnerability“. The framework decision renders this more precise by requiring that the person have „,no real and acceptable alternative but to submit to the abuse involved“. It may be disputed whether this amendment has made the provision sufficiently clear. But in any case the efforts made by the European legislators must be expressly acknowledged.

Nevertheless there are numerous legal acts which give rise to criticism. Some examples:

- Pursuant to Art. 1 (b) (ii) of the Framework Decision on combating the sexual exploitation of children and child pornography ${ }^{27}$ depictions of real persons of age appearing to be minors are considered child pornography. Whether or not a person of age appears as a minor cannot be described legally. Naturally the transition from juvenile to adult appearance takes place seamlessly - an eighteen year old woman may look like seventeen (whatever this means). This criterion will not lead to foreseeable results and is not suitable for the use in criminal law provisions.

- Under Art. 1 (2) of the Framework Decision on combating certain forms and expressions of racism and xenophobia ${ }^{28}$ Member States may choose to punish only conduct which is either carried out in a manner likely to disturb public order. It remains unclear to what this refers. While it is desirable that the European legislator confers a margin of appreciation on the Member States, it is equally problematic that they do so by providing the Member States with unclear legal terms.

- According to Art. 2 (1) of the Framework Decision on combating corruption in the private sector ${ }^{29}$ Member States are to punish both the giving and receiving sides of business corruption. It is crucial that the receiving person

\footnotetext{
${ }^{26}$ Council Framework Decision 2002/629/JHA, OJ 2002 L 203 of 1 August 2002, p. 1; comparable the Proposal for a Directive on preventing and combating trafficking in human beings, and protecting victims, repealing Framework Decision 2002/629/JHA, COM (2010) 95 final.

${ }^{27}$ Council Framework Decision 2004/68/JHA, OJ 2004 L 13 of 20 January 2004, p. 44; similar the Proposal for a Directive on combating the sexual abuse, sexual exploitation of children and child pornography, repealing Framework Decision 2004/68/JHA, Council Doc. 16958/10

${ }^{28}$ Council Framework Decision 2008/913/JHA, OJ 2008 L 328 of 6 December 2008, p. 55.

${ }^{29}$ Council Framework Decision 2003/568/JHA, OJ 2003 L 192 of 31 July 2003, p. 54.
} 
should perform or refrain from performing any act in breach of that person's duties. Art. 1 of this framework decision defines a ,breach of duty“ rather broadly. This term shall be understood according to national law but should as a minimum standard cover, any disloyal behaviour constituting a breach of statutory duty, or (...) a breach of professional regulations or instructions (...)“. In order to estimate the consequences in criminal law those who offer or promise the advantage must be capable of foreseeing the entire scope of duties which the national law imposes on the recipient. This comprises statutory law (including case law) and the legal duties derived from the individual employment contract. The lack of clarity is derived from the framework decision itself and can neither be remedied by rendering the transposing acts more precise nor by allowing the Member States to limit the framework decision's scope of application pursuant to its Art. 2 (3) to conduct involving distortions of competition in relation to the purchase of goods or commercial services.

- The Directive on the protection of the environment through criminal law $^{30}$ raises a similar problem: It describes punishable conduct by several crossreferences and thereby practically forces the national legislator to repeat these in the implementing act. This will impede the finding of justice. Multiple references between national and European law might even render it infeasible particularly due to varying wordings of this directive in other official languages and differing standards of interpretation for European and national law. Alternatively Member States could deduce the punishable conduct from the cross-references and enact many single criminal offences without them. Such an approach however is hardly practical for national legislators and not permissible when referencing Community (Union) law with direct effect. It would furthermore entail the risk of missing a combination of references and the member state would then violate its obligation to fully transpose the directive.

5. Many critics claim a neglect of the principle of subsidiarity which limits the EC / EU competence to harmonise national criminal law provisions. The legal acts relating to criminal law have in the past respected this principle to some extent.

- Exerting criminal law competences on a European level is especially justified when the EC (or EU respectively) aims at protecting its own financial or other supranational interests (e. g. protecting the Euro against counterfeiting).

- The principle of subsidiarity is also respected in fields of criminal law which involve crimes that are by trend committed transnationally and cannot be prevented on national level only. Crimes concerning international terrorism and the environment belong to this category because in the former case the offenders' organisation and in the latter case the impact of the offence do not stop at borders. Although the principle of subsidiarity will most likely be met in these cases this does not imply that all aspects of these crimes have to be dealt with on an international level.

\footnotetext{
${ }^{30}$ Directive 2008/99/EC, OJ 2008 L 328 of 6 December 2008, p. 28.
} 
- Previous attempts by the Member States in other international fora in order to harmonise certain fields of criminal law may also indicate that the principle of subsidiarity is upheld. Before the adoption of the Framework Decision on combating trafficking in human beings ${ }^{31}$ similar efforts had been made by the United Nations ${ }^{32}$ and the Council of Europe. ${ }^{33}$ Whether the principle of subsidiarity demands a solution on a national level must still be scrutinised for every single provision.

However the following examples show that the principle of subsidiarity is still not observed in many cases:

- The Framework Decision on combating certain forms and expressions of racism and xenophobia by means of criminal law ${ }^{34}$ requires the Member States to ensure that any racist public inciting to violence (Art. 1 (1) (a) - (b)) or denying of the Holocaust or other acts of genocide (Art. 1 (1) (c) - (d)) are punishable crimes. Art. 29 (1) and (2) TEU forms the current legal basis for the framework decision. However the European legislator did not substantiate well why this competence is not limited by the principle of subsidiarity especially considering the different cultural and legal traditions of the Member States in this regard. ${ }^{35}$ Instead the legislator argued that European minimum standards are justified because judicial cooperation among Member States must be improved (recital no. 4) and because they constitute a threat against certain groups of persons (recital no. 5). However improving judicial cooperation is not an end in itself. If this argument was valid, then the principle of subsidiarity would not have a scope of application in the field of criminal law because reducing the differences between national criminal law systems naturally simplifies judicial cooperation. It is not apparent that judicial assistance would be hampered without harmonising criminal law provisions. The framework decision expresses the common wish to take a stand against undoubtedly undesirable behaviour. But criminal law should not be abused for symbolic acts. In any case the principle of subsidiarity has not been applied seriously here.

- Furthermore Art. 4 of the this framework decision (on combating certain forms and expressions of racism and xenophobia) and Art. 5 (2) of the Framework Decision on combating terrorism ${ }^{36}$ also give cause for concern. Both provisions require the Member States to punish offences more severely if -

\footnotetext{
${ }^{31}$ Council Framework Decision 2002/629/JHA, OJ 2002 L 203 of 1 August 2002, p. 1.

32 Protocol to Prevent, Suppress and Punish Trafficking in Persons, Especially Women and Children, supplementing the United Nations Convention against Transnational Organized Crime (General Assembly resolution 55/25 of 15 November 2000; Entry-Into-Force on 25 December 2003): http://www.unodc.org/documents/treaties/UNTOC/Publications/TOC\%20Convention/TOCebook-e.pdf.

${ }^{33}$ Cf. Recommendation No. R(91)11 of the Committee of Ministers to Member States on sexual exploitation, pornography and prostitution of, and trafficking in, children and young adults; Recommendation No. R(2000)11 of the Committee of Ministers to Member States on action against trafficking in human beings for the purpose of sexual exploitation; Recommendation No. R(2001)16 of the Committee of Ministers to Member States on the protection of children against sexual exploitation.

${ }^{34}$ Council Framework Decision 2008/913/JHA, OJ 2008 L 328 of 6 December 2008, p. 55.

${ }^{35}$ This is not contested by the European legislator, cf. para. 6 of the recitals.

${ }^{36}$ Council Framework Decision 2002/475/JHA, OJ 2002 L 164 of 22 June 2002, p. 3.
} 
in the case of the former framework decision - they are committed in racist or xenophobic motivation or - in the case of the latter - with a terrorist intent. Although these provisions impose relatively "soft" obligations on the Member States, which might all in all be sensible and conform to their practice, they are not (and can hardly be) supported by arguments why a solely national solution does not suffice.

- In general almost all of the concerned legal acts formalistically state in one sentence that the principle of subsidiarity has been (allegedly) observed, e.g. recital no. 7 of the Framework Decision on the fight against organised crime $^{37}$ : ,Since the objectives of this Framework Decision cannot be sufficiently achieved by the Member States, and can therefore, by reason of the scale of the action, be better achieved at Union level, the Union may adopt measures, in accordance with the principle of subsidiarity (...)". However neither are the objectives of the framework decision named nor is empirical evidence provided for the assumption that the Member States lack the possibility of sufficiently achieving these objectives.

6. Finally our request for observing the principle of coherence can also be made clear by means of concrete legal acts. It must be noted that the Member States have so far been left some space in order to preserve the principle of (vertical) coherence.

- The European institutions have until now refrained from requiring the Member States to introduce criminal law sanctions for legal persons (cf. recital no. 7 of the Framework Decision on combating corruption in the private sector ${ }^{38}$; cf. supra the principle of guilt).

- For once the European legislator has tried to avoid interfering with national penalty systems. When deliberating ${ }^{39}$ upon the Framework Decision on the strengthening of the penal framework to prevent the facilitation of unauthorised entry, transit and residence ${ }^{40}$ the legislator considered introducing minimum-maximum-penalties of twelve years in Art. 1 (3). This would not have been compatible with Swedish criminal law as the maximum penalty for the corresponding offence in Sweden was four years and the highest fixedterm custodial sentence at all was ten years. In the course of the deliberations the minimum-maximum penalty was set to eight years and Art. 1 (4) of the framework decision was introduced which allows Member States to impose a lower maximum sentence if this is, imperative to preserve the coherence of the national penalty system“. This provides a good example for how the Member States" interests in keeping a coherent criminal law system can be safeguarded.

However in practice the European institutions are far from consequently following a (vertically and horizontally) coherent approach in criminal law policy.

\footnotetext{
${ }_{37}$ Council Framework Decision 2008/841/JHA, OJ 2002 L 300 of 11 December 2008, p. 42.

${ }^{38}$ Council Framework Decision 2003/568/JHA, OJ 2003 L 192, p. 54.

${ }^{39}$ Fredrik Wersäll, Politik och juridik - vad är vad i tredje pelaren? Några tankar kring symbolpolitik kontra rationalitet. In Asp, Herlitz \& Holmqvist, Festskrift till Nils Jareborg, Iustus förlag 2002 p. 659-670, (666).

${ }^{40}$ Council Framework Decision 2002/946/JHA, OJ 2002 L 328 of 5 December 2002, p. 1.
} 
- If framework decisions lack clauses like the one described above, the sanctions imposed in compliance with EU law might be out of sync with the rest of the finely balanced criminal sanctions. Art. 5 (3) of the Framework Decision on combating terrorism ${ }^{41}$ set the minimum-maximum-penalty for directing a terrorist group or participating in the activities of such a group to fifteen years and put the Finnish criminal law under pressure because the longest deprivation of liberty for a fixed term had amounted to twelve years before. The framework decision could only be transposed by implementing a maximum sentence of 12 +3 years contrary to the Finnish criminal law system.

- As shown above European legal acts sometimes establish the same sentence for conduct that is socially detrimental in different ways. Art. 3 (2) (a) of the Framework Decision on combating trafficking in human beings ${ }^{42}$ requires a minimum-maximum-penalty of eight years if a victim's life was deliberately or by gross negligence endangered when committing a trafficking offence. The same minimum-maximum-penalty is set for fraudulent making or altering of currency according to Art. 6 (2) of the Framework Decision on increasing protection by criminal penalties and other sanctions against counterfeiting in connection with the introduction of the euro ${ }^{43}$. This exemplifies that the criminal law activities undertaken by the Union lack (horizontal) coherence. ${ }^{44}$ The Member States remain free to introduce penalties which are more severe than the minimum-maximum-penalties if they consider the respective conduct more detrimental. They are however forced to at least partially raise the penalties which interferes with the principle of vertical coherence. ${ }^{45}$

- The lack of horizontal coherence can - again - be shown with the Framework Decision on combating terrorism ${ }^{46}$ which does not distinguish between the participation in a terrorist group directed towards the committing and the threatening to commit terrorist activities, whereas the minimum-maximum penalty for the directing of a terrorist group that refers only to the threatening to commit terrorist offences is reduced to eight years. Hence in such cases the same minimum-maximum-penalty is applied to both, the leader of the group and the follower.

7. The examples show that European legislation has only partly amounted to unacceptable or at least critical results. Although the line to unbearable consequences has not been crossed some alarming tendencies must be observed and not be ignored: criminal law must not be adopted without pursuing a legitimate

\footnotetext{
${ }^{41}$ Council Framework Decision 2002/475/JHA, OJ 2002 L 164 of 22 June 2002, p. 3.

42 Council Framework Decision 2002/629/JHA, OJ 2002 L 203 of 1 August 2002, p. 1.

${ }^{43}$ Council Framework Decision 2000/383/JHA, OJ 2000 L 140 of 14 June 2000, p. 1.

${ }^{44}$ Weyembergh, Approximation of criminal laws, the Constitutional Treaty and The Hague Programme, p. 1586.

45 The new Proposal for a Directive on preventing and combating trafficking in human beings, COM (2010) 95 final, raises the minimum-maximum compared to the now existing Framework Decision; this is - on the one hand consequent with a view to establishing horizontal coherence, on the other hand this approach follows a wrong basic orientation and causes problems as to the vertical coherence and the principle of proportionality.

${ }^{46}$ Council Framework Decision 2002/475/JHA, OJ 2002 L 164 of 22 June 2002, p. 3, as amended by the Council Framework Decision 2008/919/JHA, OJ 2008 L 330 of 9 December 2008, p. 21.
} 
purpose; the principle of ultima ratio must not be neglected; the Member States must not be obliged to pass imprecise national criminal laws; the legislation must not answer every social problem with passing increasingly repressive acts and consider this as a value in itself.

These worrisome tendencies can also be perceived on a national level but are significantly amplified by European developments. If the entailed risks are not acknowledged in time, we fear to be confronted with criminal laws that contradict our fundamental principles.

Prof. Dr. Petter Asp, Stockholm University, Sweden

Prof. Dr. Nikolaos Bitzilekis, Aristotle University of Thessaloniki, Greece

Lect. univ. Dr. Sergiu Bogdan, Babes-Bolyai University, Romania

Prof. Dr. Thomas Elholm, University of Southern Denmark, Denmark

Prof. Dr. Luigi Foffani, University of Modena and Reggio Emilia, Italy

Prof. Dr. Dan Frände, University of Helsinki, Finland

Prof. Dr. Helmut Fuchs, University of Vienna, Austria

Prof. Dr. Maria Kaiafa-Gbandi, Aristotle University of Thessaloniki, Greece

Prof. Dr. Jocelyne Leblois-Happe, University of Strasbourg, France

Prof. Dr. Adán Nieto Martín, University of Castilla-La Mancha, Spain

Prof. Dr. Cornelius Prittwitz, Johann Wolfgang Goethe-University Frankfurt/Main, Germany

Prof. Dr. Helmut Satzger, Ludwig-Maximilians-University Munich, Germany

Prof. Dr. Elisavet Symeonidou-Kastanidou, Aristotle University of Thessaloniki, Greece

Prof. Dr. Ingeborg Zerbes, University of Vienna, Austria 
